\title{
Pharmaciana
}

Vol.11, No.3, Nov 2021, Page. 347-354

ISSN: 2088 4559; e-ISSN: 24770256

DOI: $10.12928 /$ pharmaciana.v11i3.19105

\section{Identification SNP rs5219 KCNJ11 gene and blood glucose levels in type 2 diabetes mellitus patients at Moewardi Hospital Surakarta}

\author{
Nur Aida1, Rita Maliza ${ }^{* 2}$, Imaniar Noor Faridah', Melinda Widianingrum², \\ Dyah Aryani Perwitasari, ${ }^{1,3}$ \\ ${ }^{1}$ Postgraduate Program in Clinical Pharmacy, Faculty of Pharmacy, Universitas Ahmad Dahlan, \\ Jl. Prof. Dr. Soepomo, S.H., Warungboto,Umbulharjo, Indonesia \\ ${ }^{2}$ Program Study of Biology, Faculty of Applied Science and Technology, Universitas Ahmad Dahlan, \\ Jl. Jend. Ahmad Yani, Tamanan, Banguntapan, Bantul, Yogyakarta, Indonesia \\ ${ }^{3}$ Program Study of Pharmacy, Faculty of Pharmacy, Ahmad Dahlan University Yogyakarta, Indonesia \\ Jl. Prof. Dr. Soepomo, S.H., Warungboto, Umbulharjo, Indonesia
}

Accepted: 03-08-2021

\begin{abstract}
Diabetes Mellitus (DM) is a metabolic disease that developed due to the pancreas does not sufficient to produce insulin or the body cannot effectively use the insulin it produces. Genetic factors have an essential role in the development of Type 2 Diabetes Mellitus (DMT2), which impaired insulin production by pancreatic $\beta$ cells, insulin resistance, and action. The single nucleotide polymorphisms (SNP) in the KCNJ11 rs5219 affected the pancreatic $\beta$ cell activity that can inhibit insulin release, thus causing a decrease in therapeutic effectiveness. The purpose of this study is to identify the SNP rs5219 of the KCNJ11 gene and measure patient blood sugar levels as the outcome of therapy. A cross-sectional study was conducted prospectively at Moewardi Hospital, Surakarta, involving 10 patients with DMT2 who received sulfonylureas therapy. DNA was isolated from the whole blood sample of DMT2 patients. PCR amplification was performed to amplify the KCNJ11 gene, and followed by PCR sequencing. The 2-H PP, FPG- and $\mathrm{HbA1c}$ parameters were measured as therapeutic outcomes. The results showed that the genotype frequencies (AA-AG-GG) were $10 \%$, $50 \%$; and $40 \%$, while the allele frequency (A-G) in the sample was $35 \%$ and $65 \%$. The uncontrolled values for $2 \mathrm{H}-\mathrm{PP}$ on genotype (AA and $\mathrm{AG}+\mathrm{GG}$ ) were $10 \%$ and $20 \%$; uncontrolled $\mathrm{FPG}$ on genotypes AA and AG + GG were $10 \%$ and $40 \%$; and uncontrolled $\mathrm{HbA} 1 \mathrm{c}$ on genotype AA and AG + GG were $10 \%$ and $80 \%$. This study conclusion is the presence of the SNP rs5219 KCNJ11 gene with $\mathrm{A}>\mathrm{G}$ base change in DMT2 patients who received sulfonylurea therapy.
\end{abstract}

Keywords: Type 2 Diabetes Mellitus, Sulfonylurea, KCNJ11, rs5219, PCR-Sequencing

\author{
*Corresponding author: \\ Rita Maliza \\ Program Study of Biology, Faculty of Applied Science and Technology, Universitas Ahmad Dahlan \\ Jl. Jend. Ahmad Yani, Tamanan, Banguntapan, Bantul, Yogyakarta, Indonesia \\ Email: ritamaliza@bio.uad.ac.id
}




\section{INTRODUCTION}

Diabetes Mellitus (DM) is a complex and chronic disease that known related to mortality especially for those with prior other disease. Characterization of DM is hyperglycemia (high blood glucose levels) due to the lack of pancreatic ability to produce insulin or when the body cannot effectively use the insulin (American Diabetes Association, 2019). Globally, in 2014 an estimated 422 million adults with diabetes (Khairani, 2019). The prevalence of global diabetes is about 463 million people (9.3\%) in 2019 and will increase about $10.9 \%$ (700 million) in 2045. This prevalence known is higher in urban areas compared to rural areas (Saeedi et al., 2019). In 2018, Indonesia was ranked 7th out of 10 countries with the highest incidence of diabetes or 10.7 million. The number of diabetes cases in Central Java in 2018 was 2.1\% (Kementrian Kesehatan RI, 2020).

One of the oral hypoglycemic agents used for the management of DMT2 are sulfonylureas (SU). The mechanism of action of the sulfonylurea involves the effect of direct secretion on pancreatic beta cells (Wu et al., 2014). Genetic factors play a role in developing common DMT2 that causes impaired cell $\beta$ and insulin action. One of the genetic factors for causing changes in the Kir6.2 structure in pancreatic $\beta$ cells is polymorphism in the $K C N J 11$ gene and then affecting insulin secretion (Gupta and Vadde, 2020). KCNJ11 gene is in chromosome 11p15.1 and it codes Kir6.2 (Ahn et al., 2015), which encodes adenosine triphosphate (ATP)-sensitive K channels in pancreatic $\beta$ cells. K-ATP plays a role in the regulation of insulin secretion (Bösenberg and Van Zyl, 2008). Polymorphism in the KCNJ11 gene is one of the genetic factors that cause changes in the structure of Kir6.2 in pancreatic cells Kir6.2 which results in a decrease in insulin (Abed et al., 2013; Gupta and Vadde, 2020; Liu et al., 2015). SNP rs5219) in the KCNJ11 gene changes base A to base G, thus replacing lysine (AAG) at position 23 with glutamate $(\mathrm{GAG})(\mathrm{E} 23 \mathrm{~K})$ and identified as single nucleotide polymorphism (SNP) associated with DMT2 vulnerability (Sisi et al., 2011). The polymorphism of KCNJ11 affects the sensitivity and activity of potassium channels to ATP and then inhibits insulin secretion (Haghvirdizadeh et al., 2015).

Pharmacogenetic studies investigated the effects of KCNJ11 genotype in DMT2 patients who received sulfonylurea therapy. Studies on the Egyptian population have shown that variants of E23K on the Kir6.2 gene correlated with an increase in the risk of sulfonylurea therapy failure (Sisi et al., 2011). In contrast studies in China and Central European populations showed that the KCNJ11 gene polymorphism was associated with a good response to the sulfonylurea therapy (Javorsky et al., 2012; Li et al., 2014). Based on the study literature, the effect of KCNJ11 polymorphism on diabetes mellitus patients, especially in Indonesia is still unknown. The aim of this study is to investigate the genotyping of the KCNJ11 gene and measure blood sugar levels in DMT2 patients who use SU therapy.

\section{MATERIALS AND METHOD \\ Materials}

The Thermal Cyler T100TM (Bio-rad, US), UV transilluminator (Blupad Bio-Helix Co., Ltd, Cambridge), micropipette (Fisher brand, Pitsburg), and centrifuges (Ohaus, US) were used in this study. The materials for DNA extraction were The Favorgen Blood kit (Favorgen Biotech, Taiwan), primers forward 5'-GACTCTGCAGTGAGGCCCTA-3' and reverse 5' ACGTTGCAGTTGCCTTTTTT-3' (Macrogen, Korea), Go-Tag Green Master Mix (Promega, USA), red-gel staining (Promega, USA), nuclease-free water (Promega, USA), ladder 100 bp (Geneaid, Taiwan), loading dye (Geneaid, Taiwan), and buffer TAE (Promega, USA). Whole blood samples were collected from outpatients with diagnosis of DMT2 by the doctor at Moewardi Hospital, Surakarta. Inclusion criteria in this study were patients aged $>18$ years and DMT2 patients using sulfonylurea monotherapy. Moreover, DMT2 patients who use insulin therapy and other combination antidiabetic oral therapy, pregnant women, and patients aged less than 18 years will be excluded from this study. 


\section{Methods}

The study was cross-sectional research with prospective data retrieval. This study has been carried out in the Biology Research Laboratory of Ahmad Dahlan University Yogyakarta from August - September 2020. The study was approved by the Ahmad Dahlan University Ethics Committee (EC) (No. 011904040) and Moewardi Hospital, Surakarta.

DNA was extracted from $200 \mu \mathrm{l}$ whole blood sample by using FavorPrep Kit method ${ }^{\mathrm{TM}}$ (Favorgen Biotech, Taiwan), and DNA extraction protocol was carried out by following the manufacturer's instructions. The quality of DNA was analyzed using gel electrophoresis (Bio-rad, USA) and ultraviolet-visible spectrophotometry. Amplification of KCNJ11 gene was done by polymerase chain reaction (PCR) method using forward and reverse primers in the following conditions: Initial denaturation at $95^{\circ} \mathrm{C}$ for 5 minutes, denaturation at $95^{\circ} \mathrm{C}$ for 30 seconds, annealing at $60^{\circ} \mathrm{C}$ for 30 seconds, extensions at $72^{\circ} \mathrm{C}$ for 30 seconds and final extensions at $72^{\circ} \mathrm{C}$ for 9 minutes $(35$ cycles) (Makhzoom et al., 2019). The product of the PCR was analyzed by using electrophoresis. The agarose concentration and electricity of electrophoresis running were $1.5 \%$ and 80 volts for 80 minutes (product size $210 \mathrm{bp}$ ), respectively. The products of PCR were sent to 1st BASE Singapore for sequencing analysis. DNA sequences were edited by using the SNAP gene program. DNA sequences from the 10 samples were compared with the NCBI of SNP rs5219 database to identify SNP rs5219 of the KCNJ11 gene.

\section{Data Analysis}

Descriptive demographic characteristics of the patient include age, gender, education, and occupation. Genotype identification was analyzed by using the BioEdit and Genious software. SPSS 23 (SPSS Inc., Chicago, IL, USA) was performed for statistical analysis.

\section{RESULT AND DISCUSSION \\ Results}

The total samples in the study were 10 DMT2 (five male and five female) patients who received sulfonylurea monotherapy. The age of patients ranged from 58 to 80 years and the average age is 69 years old. Out of 10 patients, eight patients (80\%) were basic education graduates, and they are working. The average of fasting plasma glucose (FPG) levels is $219 \mathrm{mg} / \mathrm{dl}, 2$-hour postprandial blood glucose (2-H PP) is $176.40 \mathrm{mg} / \mathrm{dl}$, and HbAlc level is $8.06 \%$. Table 1 showed the demographic and clinical characteristics of the DM patients.

Table 1. Demographic and clinical characteristics of the DM patients

\begin{tabular}{llll}
\hline Characteristics & Patients (Total: 10) & N $(\%)$ & Average \pm SD \\
\hline Gender & Male & $5(50 \%)$ & \\
& Female & $5(50 \%)$ & \\
Education & Basic (Elementary, Junior & $8(80 \%)$ & \\
& High) & $2(20 \%)$ & \\
& Height (D1,S1,S2) & & \\
Job & Working & $8(80 \%)$ & \\
& Not working & $2(20 \%)$ & \\
Age & & & $69.20 \pm 8.9$ \\
FPG & & & $219.0 \pm 111.58$ \\
2-H PP & & $176.40 \pm 132.06$ \\
HbA1c & & $8.06 \pm 1.88$ \\
\hline
\end{tabular}

Legend:

FPG : fasting plasma glucose

2-H PP : 2-hour postprandial

HbA1c : hemoglobin A1c 
The range concentration of DNA samples was $70-890 \mathrm{ng} / \mu \mathrm{l}$, with an average of $210 \mathrm{ng} / \mu \mathrm{l}$. The purity index range was 1.5 to 2.3. Electropherogram bands of the KCNJ11 gene have shown that DNA amplification process by using PCR was carried out successfully (Figure.1).

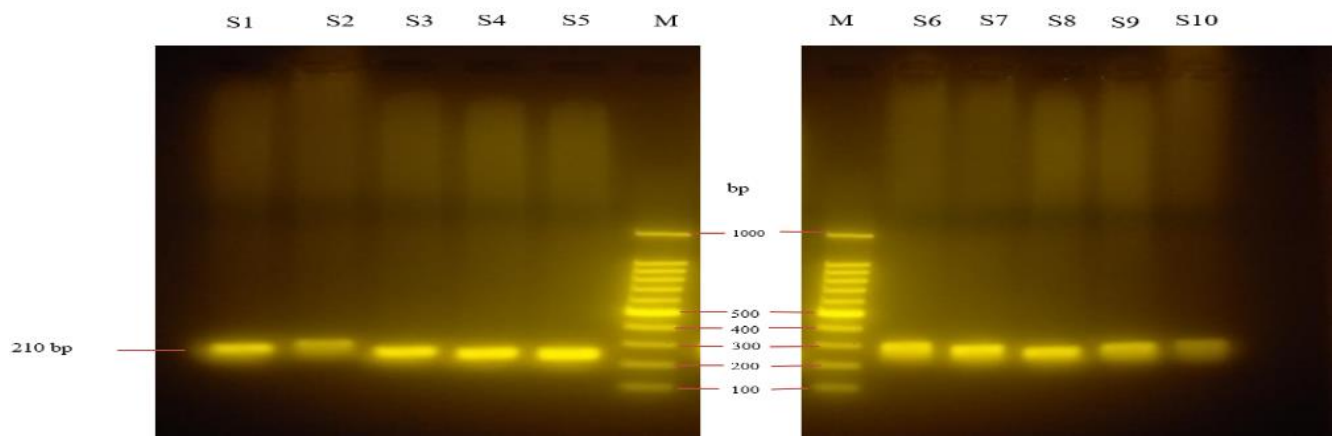

Figure 1. PCR product KCNJ11 gene on agarose gel with band size 210 bp, (M: DNA Ladder)

The sequence of the KCNJ11 gene was identified by using the Sanger Sequencing method. The point mutation in codon 23 resulted in changes in glutamic acid (E) from lysine (K) caused by the change of adenine (A) to guanine (G) (Figure 2). Four samples were homozygote mutant $(\mathrm{G} / \mathrm{G})$, five samples were heterozygote mutant $(\mathrm{A} / \mathrm{G})$, and one sample was homozygote wildtype (A/A).

A
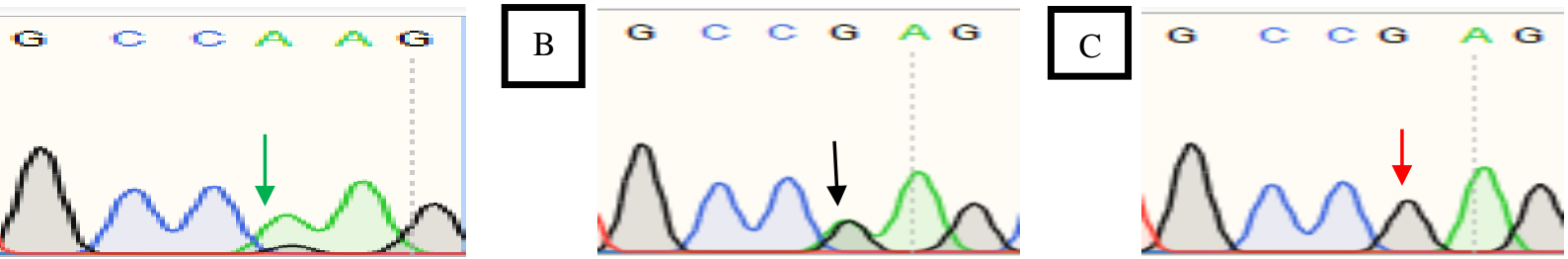

Figure 2. Electropherogram sequencing point mutation in the KCNJ11 gene. $\mathrm{A}=\mathrm{KCNJ11}$ wildtype AA gene sequencing (AAG; lysine). $\mathrm{B}=K C N J 11$ gene sequencing mutation point heterozygous AG (AAG $\rightarrow$ GAG; lysine $\rightarrow$ glutamic acid). $\mathrm{C}=$ KCNJ11 gene sequencing mutation of GG heterozygous point $(A A G \rightarrow$ GAG; lysine $\rightarrow$ glutamic acid)

SNP rs5219 of $K C N J 11$ gene mutation in 10 samples obtained the percentage of allele G greater than allele A. The distribution of A/A genotype (homozygous wildtype) has a percentage of $1 \%, \mathrm{G} / \mathrm{G}$ (homozygous mutant) has 40\%, and A/G genotype (heterozygous mutant) has 50\% (Table 2). Table 3 shows the data of blood sugar level (2-H PP, FPG, and HbA1c) and genotype distribution of patients.

Table 2. Frequency of genotype and allele distribution in $K C N J 11$ gene polymorphism Patients $(\mathbf{n}=10)$

\begin{tabular}{ll}
\hline Genotypes & \\
Wild type (AA) & $1(10 \%)$ \\
Mutant heterozygous (AG) & $5(50 \%)$ \\
Mutant homozygote (GG) & $4(40 \%)$ \\
Allele & \\
A & $0.35(35 \%)$ \\
G & $0.65(65 \%)$ \\
\hline
\end{tabular}


Table 3. Results of genotype distribution and blood sugar levels of patients $(n=10)$

\begin{tabular}{llll}
\hline & & \multicolumn{2}{c}{ Genotypes } \\
\cline { 3 - 4 } & & AA & AG+GG \\
\hline \multirow{2}{*}{ 2H-PG } & Controlled & 0 & $7(70 \%)$ \\
& Uncontrolled & $1(10 \%)$ & $2(20 \%)$ \\
\multirow{3}{*}{ HbA1c } & Controlled & 0 & $5(50 \%)$ \\
& Uncontrolled & $1(10 \%)$ & $4(40 \%)$ \\
& Controlled & 0 & $1(10 \%)$ \\
& Uncontrolled & $1(10 \%)$ & $8(80 \%)$ \\
\hline
\end{tabular}

Legend:

FPG : fasting plasma glucose

2-H PP : 2-hour postprandial

HbA1c : hemoglobin A1c

\section{DISCUSSION}

In this study, patients were mostly elderly. The prevalence of diabetes in 2018 was based on the age of DMT2 patients among 55-64 to 65-74 years (Khairani, 2019). The gender percentage of patients in this study is female (50\%) and male (50\%). However, several studies have reported there is no significant correlation between gender and blood sugar levels (Ezenwaka et al., 2005; Komariah and Rahayu, 2020). In previous study, it was found that education level is one of factors that related with the incidence of diabetes mellitus in Indonesia. Low education levels were about 1.27 times at risk of diabetes mellitus disease (). Individuals with low education had a chance of paying less attention to lifestyle, diet, and knowledge in prevent DMT2 (Felea et al., 2014). About 8 DM patients in the study were employed, in contrast to a meta-analysis study, showing the association between unemployment and impaired glucose metabolism 1.6-fold for prediabetes and 1.7-fold for DMT2 compared to those used (Varanka-Ruuska et al., 2018).

The study investigated the point mutation of the KCNJ11 gene (SNP rs5219) and blood sugar levels of patients who received oral sulfonylurea therapy. The study found there were three polymorphisms of the KCNJ11 gene on rs5219 (AA- AG- GG). Two samples were homozygous mutant $(\mathrm{G} / \mathrm{G})$, and two samples were heterozygous $(\mathrm{A} / \mathrm{G})$ with fasting blood sugar levels and HbA1c uncontrolled. In the nine samples recorded as the mutation $(A / G+G / G)$, eight patients had uncontrolled HbA1c scores. This data was similar to El Sisi et.al (2011) in the Egyptian population. The rs5219 mutations were associated with secondary failure of sulfonylurea in patients having rs5219 mutations. The previous study also reported that $50 \%$ of DMT2 volunteers who failed in the sulfonylurea therapy treatment had 56\% mutations in the KCNJ11 gene (Sisi et al., 2011). Song et.al (2017) reported several genes to affect insulin secretion from $\beta$ cells. The personalized treatment, which adjusts the sulfonylurea therapy of DMT2 patients according to the KCNJ11, ABCC8, and TCF7L2 genotype, is important to achieve the optimal treatment efficacy. Sulfonylurea inhibits the K-ATP channel through an ATP-dependent pathway that causes increased insulin secretion (Sesti et al., 2006). The mutations of the $K C N J 11$ gene affect the regulation of insulin secretion. Therefore this mechanism may affect the clinical response to sulfonylurea.

The data in shows that one sample (heterozygous mutant $\rightarrow \mathrm{A} / \mathrm{G}$ ) has normal levels of 2-H PP, FPG, and HbA1c. This data is comparable with studies in the Caribbean population. They reported that SNP rs5219 variant does not increase the worsening of metabolic control conditions in carriers of E23K genotype group. Furthermore, sub-analysis result showed that their study is consistent to support that SNP rs5219 of $K C N J 11$ gene mutations do not increase the biochemical risk of diabetes in carriers of SNP rs5219 mutations (Ezenwaka et al., 2005). These results were also similar in the Caucasian population. Sulfonylurea therapy treatment affected the patients, which had SNP rs5219 KCNJ11 gene mutations (Javorsky et al., 2012). Another study of Italian patients demonstrated that patients who presence the allele mutations ( $\mathrm{K}$ allele carriers $\mathrm{E} 23 \mathrm{~K}+\mathrm{K} 23 \mathrm{~K}$ ) increase the probability to secondary failure to sulfonylurea, which means a condition that failed to achieve FPG > $300 \mathrm{mg} / \mathrm{dl}(16.7 \mathrm{mmol} / \mathrm{l})$ 
(Sesti et al., 2006). The study had one sample with homozygotes wildtype (A/A), but the level of blood glucose (2H-PP, FPG, and HbA1c) was uncontrolled. The previous study reported that there was no relationship between E23K and L270P KCNJ11 gene polymorphism and sulfonylurea therapy response. This result was based on the measured value of FPG level in the first year therapy but not the HbA1C level (Gloyn et al., 2001). Some factors affected the response of therapy in the patient with homozygote wild types, such as glucose intake, patient compliance with therapy, and drugs that can affect blood glucose levels.

The study of polymorphism KCNJ11 gene and correlation with blood sugar levels in DMT2 patients is important in developing individualized therapy in patients with DMT2. Further research still needs to be done on other variations of gene mutation and increase the number of samples

\section{CONCLUSION}

Identification of SNP rs5219 of KCNJ11 (A/A) gene in the patients DMT2 at Moewardi hospital, Surakarta have found the SNP rs5219 with A>G base change in DMT2 patients who received sulfonylurea therapy.

\section{ACKNOWLEDGEMENT}

Thank you to the staff at Moewardi Hospital, Surakarta and the Biomedical Laboratory of the Program study of Pharmacy and Research Laboratory of the Program study of Biology, Ahmad Dahlan University.

\section{REFERENCES}

Abed, A. A., Ayesh, B. M., \& Hamdona, O. M. (2013). Single nucleotide polymorphism E23K of KCNJ11 gene and other risk factors associated with type-2 diabetes mellitus in Gaza. International Journal of Chemical and Life Sciences, 2(04), 1146-1152

Ahn, S. Y., Kim, G. H., \& Yoo, H. W. (2015). Successful sulfonylurea treatment in a patient with permanent neonatal diabetes mellitus with a novel KCNJ11 mutation. Korean Journal of Pediatrics, 58(8), 309-312. https://doi.org/10.3345/kjp.2015.58.8.309

American Diabetes Association. (2019). Introduction:Standardsofmedical care in diabetesd2019. In Diabetes Care (Vol. 42, Issue December 2018, pp. S1-S2). https://doi.org/10.2337/dc19-SINT01

Bösenberg, L. H., \& Van Zyl, D. G. (2008). The mechanism of action of oral antidiabetic drugs: A review of recent literature. In Journal of Endocrinology, Metabolism and Diabetes of South Africa (Vol. 13, Issue 3, pp. 80-89). https://doi.org/10.1080/22201009.2008.10872177.

Ezenwaka, C. E., Kalloo, R., Uhlig, M., Schwenk, R., \& Eckel, J. (2005). The E23K variant in the Kir6.2 subunit of the ATP-sensitive $\mathrm{K}+$ channel does not augment impaired glucose tolerance in Caribbean subjects with a family history of type 2 diabetes. Journal of Endocrinology, 185(3), 439-444. https://doi.org/10.1677/joe.1.06117

Felea, M. G., Covrig, M., Mircea, I., \& Naghi, L. (2014). Socioeconomic status and risk of type 2 diabetes mellitus among an elderly group population in romania. Procedia Economics and Finance, 10(14), 61-67. https://doi.org/10.1016/s2212-5671(14)00278-0

Gloyn, A. L., Hashim, Y., Ashcroft, S. J. H., Ashfield, R., Wiltshire, S., \& Turner, R. C. (2001). Association studies of variants in promoter and coding regions of beta-cell ATP-sensitive Kchannel genes SUR1 and Kir6.2 with Type 2 diabetes mellitus (UKPDS 53). Diabetic Medicine, 18(3), 206-212. https://doi.org/10.1046/j.1464-5491.2001.00449.x

Gupta, M. K., \& Vadde, R. (2020). A computational structural biology study to understand the impact of mutation on structure-function relationship of inward-rectifier potassium ion channel Kir6.2 in human. Journal of Biomolecular Structure and Dynamics, 0(0), 1-24. https://doi.org/10.1080/07391102.2020.1733666

Haghvirdizadeh, P., Mohamed, Z., Abdullah, N. A., Haghvirdizadeh, P., Haerian, M. S., \& Haerian, B. S. (2015). KCNJ11: Genetic polymorphisms and risk of diabetes mellitus. Journal of Diabetes 
Research, 2015, 1-9. https://doi.org/10.1155/2015/908152

Irawan, D. (2010). Prevalensi dan faktor risiko kejadian diabetes melitus tipe 2 di daerah Urban Indonesia. In Universitas Indonesia. Universitas Indonesia.

Javorsky, M., Klimcakova, L., Schroner, Z., Zidzik, J., Babjakova, E., Fabianova, M., Kozarova, M., Tkacova, R., Salagovic, J., \& Tkac, I. (2012). KCNJ11 gene E23K variant and therapeutic response to sulfonylureas. European Journal of Internal Medicine, 23(3), 245-249. https://doi.org/10.1016/j.ejim.2011.10.018

Kementrian Kesehatan RI. (2020). Infodatin tetap produktif, cegah, dan atasi Diabetes Melitus 2020. In Pusat Data dan Informasi Kementrian Kesehatan RI (pp. 1-10). Kementrian Kesehatan.

Khairani. (2019). Hari Diabetes Sedunia Tahun 2018. Pusat Data Dan Informasi Kementrian Kesehatan RI, 1-8

Komariah, K., \& Rahayu, S. (2020). Hubungan usia, jenis kelamin dan indeks massa tubuh dengan kadar gula darah puasa pada pPasien diabetes melitus tipe 2 di klinik pratama rawat jalan proklamasi, Depok, Jawa Barat. Jurnal Kesehatan Kusuma Husada, January, 41-50. https://doi.org/10.34035/jk.v11i1.412

Li, Q., Chen, M., Zhang, R., Jiang, F., Wang, J., Zhou, J., Bao, Y., Hu, C., \& Jia, W. (2014). KCNJ11 E23K variant is associated with the therapeutic effect of sulphonylureas in Chinese type 2 diabetic patients. Clinical and Experimental Pharmacology and Physiology, 41(10), 748-754. https://doi.org/10.1111/1440-1681.12280

Liu, N. J., Wu, H. H., Li, Y. L., Yang, Z., Tao, X. M., Du, Y. P., Wang, X. C., Lu, B., Zhang, Z. Y., Hu, R. M., \& Wen, J. (2015). An analysis of the association between a polymorphism of KCNJ11 and diabetic retinopathy in a Chinese Han population. European Journal of Medical Research, 20(1), 1-7. https://doi.org/10.1186/s40001-014-0075-3

Makhzoom, O., Kabalan, Y., \& Al-Quobaili, F. (2019). Association of KCNJ11 rs5219 gene polymorphism with type 2 diabetes mellitus in a population of Syria: A case-control study. $B M C$ Medical Genetics, 20(1), 1-6. https://doi.org/10.1186/s12881-019-0846-3

Saeedi, P., Petersohn, I., Salpea, P., Malanda, B., Karuranga, S., Unwin, N., Colagiuri, S., Guariguata, L., Motala, A. A., Ogurtsova, K., Shaw, J. E., Bright, D., \& Williams, R. (2019). Global and regional diabetes prevalence estimates for 2019 and projections for 2030 and 2045: Results from the International Diabetes Federation Diabetes Atlas, 9th edition. Diabetes Research and Clinical Practice, 157(January), 107843. https://doi.org/10.1016/j.diabres.2019.107843

Sesti, G., Laratta, E., Cardellini, M., Andreozzi, F., Del Guerra, S., Irace, C., Gnasso, A., Grupillo, M., Lauro, R., Hribal, M. L., Perticone, F., \& Marchetti, P. (2006). The E23K variant of KCNJ11 encoding the pancreatic $\beta$-cell adenosine 5 '-triphosphate-sensitive potassium channel subunit Kir6.2 is associated with an increased risk of secondary failure to sulfonylurea in patients with type 2 diabetes. Journal of Clinical Endocrinology and Metabolism, 91(6), 2334-2339. https://doi.org/10.1210/jc.2005-2323

Sisi, A. E., Metwally, S. S., \& Dawood, N. A. (2011). Effect of genetic polymorphisms on the development of secondary failure to sulfonylurea in Egyptian patients with type 2 diabetes. Therapeutic Advances in Endocrinology and Metabolism, 2(4), 155-164. https://doi.org/10.1177/2042018811415985

Song, J., Yang, Y., Mauvais-Jarvis, F., Wang, Y. P., \& Niu, T. (2017). KCNJ11, ABCC8 and TCF7L2 polymorphisms and the response to sulfonylurea treatment in patients with type 2 diabetes: A bioinformatics assessment. BMC Medical Genetics, 18(1), 1-17. https://doi.org/10.1186/s12881$\underline{017-0422-7}$

Varanka-Ruuska, T., Rautio, N., Lehtiniemi, H., Miettunen, J., Keinänen-Kiukaanniemi, S., Sebert, S., \& Ala-Mursula, L. (2018). The association of unemployment with glucose metabolism: a systematic review and meta-analysis. International Journal of Public Health, 63(4), 435-446. https://doi.org/10.1007/s00038-017-1040-Z 
Wu, Y., Ding, Y., Tanaka, Y., \& Zhang, W. (2014). Risk factors contributing to type 2 diabetes and recent advances in the treatment and prevention. In International journal of medical sciences, 11(11), 1185-1200). https://doi.org/10.7150/ijms.10001 